Bulletin of Pharmaceutical Sciences
Assiut University
Website: http://bpsa.journals.ekb.eg/
e-mail: bullpharm@aun.edu.eg

\title{
PHYTOCHEMICAL STUDY AND PROTECTIVE EFFECT INVESTIGATION AGAINST OXIDATIVE DAMAGE IN HUMAN ERYTHROCYTES OF SYRIAN ASTERACEAE PLANTS
}

\author{
M.Kinan Aljaja ${ }^{1 *}$, Raghda Lahdo ${ }^{2}$ and Adawia Kitaz ${ }^{1}$ \\ ${ }^{1}$ Department Of Pharmacognosy and medicinal plants, Faculty of Pharmacy, University of Aleppo, \\ Syria \\ ${ }^{2}$ Department Of Biochemistry and Microbiology, Faculty of Pharmacy, University of Aleppo, Syria
}

\begin{abstract}
Oxidative stress is a major cause of many diseases, it can damage the tissues and lead to lipid peroxidation and DNA strand breakage. Nowadays, researchers have centered medicinal plants in their concern, to benefit from their active component as antioxidant reagents. This study aims to investigate the protective and hemolytic activity, as well as qualitative and quantitative chemical content of plants from Syrian Flora. Ethanol $70 \%$ extracts of three plants of Asteraceae; Onopordum carduiforme, Centaurea verutum, and Achillea santolina were prepared to test their protective antioxidant effect on erythrocytes membrane against the oxidative hemolysis which was induced using AAPH. The hemolytic effect of these plants was also evaluated. In addition to the quantitative content of phenols TPC and flavonoids TFC compounds using Folin-Ciocalteu and aluminum chloride colorimetric methods respectively. The basic phytochemical screening was conducted using the standard methods.The results showed a low hemolytic effect of the extracts on erythrocytes, using the concentrations of $(1-5 \mathrm{mg} / \mathrm{ml})$. Moreover, they reduced membrane lipid peroxidation significantly; where $O$. carduiforme showed the highest efficacy of protective activity against hemolytic damage. The phytochemical screening of the plants' extracts showed phenols, flavonoids, tannins, coumarins, cardiac glycosides, terpenoids, steroids, and carbohydrates presence, whereas no alkaloids or saponins were found. TPC and TFC content ranges were between $(9.22 \pm 0.412$ and $13.716 \pm$ $0.431 \mathrm{mg} \mathrm{GAE} / \mathrm{g} \mathrm{DW})$ and $(2.224 \pm 0.346$ and $8.958 \pm 0.216 \mathrm{mg}$ RUE/g DW) respectively.
\end{abstract}

\section{INTRODUCTION}

Many disorders are caused by oxidative stress; these diseases may cause harmful effects on tissues or organs, which lead subsequently to lipid peroxidation and DNA strand breakage. The presence of hemoglobin, unsaturated fatty acids, and oxygen, may make erythrocytes more prone to oxidative damage, which cause membrane disruption and eventually hemolysis. Erythrocytes normally have a strong antioxidant activity, that includes enzymatic and non-enzymatic mechanisms, which act together efficiently to change ROS species into less reactive intermediate types. Unfortunately, these defense capabilities are limited, because mature erythrocytes lack the synthesis of antioxidative enzymes. Antioxidant agents such as vitamins $\mathrm{C}, \mathrm{E}$, and $\mathrm{A}$ can help in the prevention and treatment of many oxidative-mediated erythrocyte damages ${ }^{1 .}$

Plants have been used by the public for thousands of years, all over the world and in

Received in 7/3/2021 \& Accepted in 6/5/2021 
many aspects. According to the World Health Organization, $80 \%$ of the world's population uses plant-based remedies as their primary form of healthcare. In some countries, such as in Europe herbal medicines have an ancient history and tradition ${ }^{2}$. Medicinal plants contain hundreds, if not thousands, of chemicals that interact in complicated ways, giving many bioactive effects. Despite that their traditional medicinal benefits are scarcely proven, some scientifically documented components are wellknown to give the plants their medicinal and therapeutic properties, such as essential oils, phenolic compounds, alkaloids ${ }^{3}$.

Onopordum carduiforme, Centaurea verutum, and Achillea santolina that represent the selected plants in this study belong to the Asteraceae family, which is one of the largest families in the plant kingdom, with an estimated number of 25,000 species spreading in wide areas. Additionally, this family comes second in Syria in terms of species figures (400 species in Syria). The Taxonomical classification of these plants is as follows: (kingdom: Plantae, Phylum: magnoliophyte, class: Magnoliopsida (Dicotyledons), order: Asterales, family: Asteraceae $)^{4-7}$.

Onopordum carduiforme is a biennial or perennial herb, 30-100 cm height, sparsely cobwebbed, stem erect, much-branched; wings consisting of triangular long-spiny lobes connected by a narrow green margin, leaves are almost glabrous on the upper face, often cobwebbed and greyish on the lower, florets dark purple ${ }^{8}$. Onopordum genus has been widely used in folkloric treatments, as refreshing, invigorating, and the treatment of inflammatory diseases and kidney problems ${ }^{9-11}$. Various studies have demonstrated the efficacy of antihypertensive, antioxidant, and antibacterial properties of other species of Onopordum ${ }^{12-16}$. These therapeutic properties are related to the wide range of secondary metabolites content, such as phenolic compounds, lignans, sesquiterpene lactones, coumarins, terpenes, and steroids ${ }^{17}$.

Centaurea verutum is an annual plant, 50$130 \mathrm{~cm}$ height, stem rigid, erect, simple, or with erect branches; stem and leafy branches, lower leaves are mostly sinuate, other leaves are entire, oblong, the florets are yellow ${ }^{8}$. This plant was used as an expectorant, antidiabetic, antipyretic, and antidiarrheal in Turkey, and to treat infections, stomach ache, edema, arthritis, and pain in Northern Nigeria ${ }^{18 \& 19}$. Several studies have confirmed that species of Centaurea have antibacterial and antioxidant properties ${ }^{19 \& 20}$.

Achillea santolina is a perennial herb, 15$30 \mathrm{~cm}$ height, woolly, stems erect to ascending, simple or branched, leafy up to the inflorescence, leaves narrow, linear, green ${ }^{8}$. In Syria, the genus of Achillea has been used traditionally for the treatment of gallbladder stones, anticancer, and atherosclerosis ${ }^{21}$ and used to treat liver and kidney, digestive, cold, and high blood pressure diseases. Moreover, it has anti-inflammatory, antihelminthic, antiseptic for urinary tract infections, and antihyperglycemia properties ${ }^{22 \& 23}$. Pharmacological studies have shown that $A$. santolina has a different chemical and therapeutic properties as an antioxidant and anticancer properties ${ }^{24}$. Other studies have showed the efficacy of antihypertensive, antidiabetic, and antihyperlipidemia ${ }^{25 \& 26}$. In addition to that, it has a proven inhibitory activity on wide spectrum of bacteria species and leishmania ${ }^{27}$.

Unfortunately, there are no sufficient scientific studies on Syrian Flora plants, especially in terms of investigating the biological activity. Furthermore, the Asteraceae members we chose have not received much attention in the literature and a little is known about these plants. As far as our knowledge is concerned, no research articles dedicated to these plants have been published in Syria of the same methodology aspects. Consequently, this study aimed to demonstrate the phytochemical constituents, determine the antioxidant compounds (phenols and flavonoids) of the three plants. In addition to conducting a biological study, that includes investigating the potential hemolytic effect of the plant towards human erythrocytes membranes and the protective antioxidant effect against the induced oxidative hemolysis that is caused using in vitro model of AAPH (2,2-azobis 2amidinopropane dihydrochloride). 


\section{MATERIALS AND METHODS}

\section{Chemicals and Equipment}

Chemicals: Ethanol GR (Eurolab, UK), Folin-ciocalteu phenol reagent (Sigma-Aldrich, Switzerland), Sodium Carbonate anhydrous (PAREAC QUIMICA SAU, Spain), Gallic acid (Titan biotech LTD., India), Rutin (ExtrasyntheseGenay, France), Aluminum Chloride Hexahydrate (Scharalau Chemie, Spain), Distilled deionized water (d.H2O), Triton- X100 (Roth, Germany), 2,2- azobis 2amidinopropane dihydrochloride (SigmaAldrich, USA), Vitamin C

Equipment: Sensitive balance (Sartorius TE214, Germany), Rotary evaporator (Heidolph Instruments, Germany), UV-1800 spectrophotometer (Shimadzu, Japan), Ultrapure TM water purification system (Lotun Co., Ltd., Taipei, Taiwan), Centrifuge Germany, (HeraeusMegafuge), ultrasonic bath (POWERSONIC 405, Hwashin Technology Co., Korea), Disposable Syringes 5, $10 \mathrm{ml}$ (UK), EDTA tub (China), Eppendorf Tubes.

\section{Plant Material}

Fresh aerial parts (stems, flowers, leaves) of $O$. carduiforme, $C$. verutum, $A$. santolina were collected from different areas of the Aleppo Governorate in Syria. Plant specimens were identified by Dr. Ahmed Jadouh, Professor and expert at the Faculty of Agricultural Engineering, Aleppo University, Syria. The aerial parts were washed under running tap water, shade dried, then powdered using a mechanical grinder and kept in an airtight glass container until use.

\section{METHODS}

\section{Preparation of extracts}

The powdered plant samples $(130 \mathrm{~g}$ of each plant) were extracted by Ultrasonication Assisted Extraction, using ten folds of ethanol $70 \%$ at $40^{\circ} \mathrm{C}$ for one hour. The extracts solutions were then filtered through Whatman No. 1 filter papers, and the residual material was re-extracted three times using the same procedure. The combined extracts were evaporated using the rotary evaporator at $40^{\circ} \mathrm{C}$ to remove the solvent. The crude extracts were kept separately in sterile sample tubes and stored at $4^{\circ} \mathrm{C}$ for further usage ${ }^{28 \& 29}$.

The yield percentage was then calculated using the following equation:

$$
\text { Yield }(\%)=\mathrm{W}_{\mathrm{ex}} / \mathrm{W}_{\mathrm{p}} * 100
$$

Where $\mathrm{W}_{\mathrm{ex}}$ is the weight of the dried extract and $W_{p}$ is the weight of the dried plant material ${ }^{30}$.

\section{Phytochemical screening}

Phytochemical examinations were carried out for the plants' extracts as per the standard methods ${ }^{31}$. Three plants were screened for their phytochemical components of phenols, flavonoids, alkaloids, tannins, saponins, coumarins, cardiac glycosides, terpenoids, steroids, and carbohydrates ${ }^{32-38}$. (Table 1).

Table 1:: Phytochemical examinations for plants extract by using standard methods

\begin{tabular}{|c|c|c|c|}
\hline Plants constituent & Test/Reagent used & Plants constituent & $\begin{array}{l}\text { Test/Reagent used } \\
\end{array}$ \\
\hline \multirow{2}{*}{ Phenols } & Ferric Chloride & \multirow{2}{*}{ Saponins } & foam \\
\hline & Folin Ciocalteu & & aromatic aldehydes \\
\hline \multirow{3}{*}{ Flavonoids } & Aluminum chloride & Coumarins & fluorescence \\
\hline & Shinoda test & \multirow{2}{*}{ Cardiac Glycosides } & Killer-Killiani \\
\hline & Pew's Tests & & Kedde \\
\hline \multirow{2}{*}{ Alkaloids } & Dragendroff & \multirow{2}{*}{ Terpenoids } & S Salkowski test \\
\hline & Mayer's & & Libermann Burchard's \\
\hline \multirow{3}{*}{ Tannins } & Ferric chloride & \multirow{2}{*}{ Carbohydrates } & Molisch's \\
\hline & Lead acetate test & & Fehling's \\
\hline & Vanillin & $\begin{array}{l}\text { Cyanogenic } \\
\text { Glycosides }\end{array}$ & Picrate paper \\
\hline
\end{tabular}




\section{Determination of total phenolic contents (TPC)}

The total phenolic content of the plants' extracts was determined spectrophotometrically by using Folin-Ciocalteu's reagent. $2.5 \mathrm{ml}$ of $10 \%$ Folin-Ciocalteu's reagent diluted in distilled water $\left(\mathrm{d} \mathrm{H}_{2} \mathrm{O}\right)$, was mixed with $0.5 \mathrm{ml}$ of each extract solution of the concentration $(0.5 \mathrm{mg} / \mathrm{ml})$ in (ethanol $70 \%)$ solvent; the mixture was placed for few min, and then 2.5 $\mathrm{ml}$ of $7.5 \% \mathrm{Na}_{2} \mathrm{CO}_{3}$ was added, the sample was incubated afterward at $45^{\circ} \mathrm{C}$ for $45 \mathrm{~min}$. In the end, the absorbance was read using a spectrophotometer at $\lambda_{\max }=765 \mathrm{~nm}$ against the blank solution which contains $0.5 \mathrm{ml}$ solvent, $2.5 \mathrm{ml} 10 \% \mathrm{~F}-\mathrm{C}$ reagent, and $2.5 \mathrm{ml}$ of $7.5 \%$ sodium carbonate. Each test was done in triplicate. The samples were independently prepared in triplicate for each analysis and the mean value of three absorbance was obtained. The same procedures were repeated for the standard solution of Gallic acid in distilled water $\left(\mathrm{d} \mathrm{H}_{2} \mathrm{O}\right)$ as a standard series (from 0.01 to $0.08 \mathrm{mg} / \mathrm{ml}$ ) the liner calibration was construed. Based on the measured absorbance, the concentration of phenolic compounds was calculated from the equation of the calibration line. The content of phenolic in each extract was expressed in terms of milligrams of gallic acid equivalent per gram of plant dry weight or $\mathrm{mg}$ of gallic acid equivalent per gram of dry extract (mg GAE/g DW, mg GAE/g extract) ${ }^{39}$.

\section{Determination of total flavonoid content (TFC)}

The content of flavonoids in the extracts of the examined plants was determined using the spectrophotometric method. The test sample contained $1 \mathrm{ml}$ of (ethanol 70\%) solution of the extract in the concentration of 1 $\mathrm{mg} / \mathrm{ml}$ for $O$. carduiforme, and $0.5 \mathrm{mg} / \mathrm{ml}$ for both $C$. verutum and $A$. santolina, in addition to $1 \mathrm{ml}$ of $2 \% \mathrm{AlCl}_{3}$ solution dissolved in methanol. The samples were incubated for an hour at room temperature. The blank sample consists of $1 \mathrm{ml}$ extract solution with $1 \mathrm{ml}$ methanol without $\mathrm{AlCl}_{3}$. The absorbance was read using a spectrophotometer at $\lambda_{\max }=415$ $\mathrm{nm}$. The samples were prepared in triplicate for each analysis and the mean value of absorbance was obtained. The same procedure was repeated for the standard solution of rutin in ethanol $(0.005$ to $0.6 \mathrm{mg} / \mathrm{ml})$ and the calibration line was construed. Based on the measured absorbance, the concentration of flavonoids was calculated from the equation of the calibration line. Then, the content of flavonoids in extracts was expressed in terms of milligrams of rutin per gram of plant or $\mathrm{mg}$ of gallic acid equivalent per gram of dry extract (mg RUE/g DW, mg RUE/g extract) ${ }^{39}$.

\section{Hemolysis test ${ }^{40 \& 41}$}

This test evaluates the effect of the plants' extracts on the red blood cells, to investigate whether they have a hemolytic effect or not, by using increased concentrations of the plants' extracts. Fresh human blood samples were taken from healthy volunteers being granted permission, non-smokers, with an average age of 25 years. The blood was collected in EDTAcontaining tubes (Ethylene Diamine Tetra Acetic acid) as an anticoagulant, and centrifuged (at $2500 \mathrm{rpm}$ for $10 \mathrm{~min}$., at temperature $\left(20-25^{\circ} \mathrm{C}\right)$. After that, the plasma was washed three times or more (with PBS 10 mmol $\mathrm{pH}=7.4$ ) until plasma and buffy coat removal. The red blood cells suspension (RBC) $(10 \%-\mathrm{v} / \mathrm{v})$ was prepared in (PBS). A mixture of $2.5 \mathrm{ml}$ of $10 \%$ RBC suspension with $500 \mu \mathrm{L}$ of the plants extract at the concentrations of $(1,2,3,4$ and 5$) \mathrm{mg} / \mathrm{ml}$ prepared in (PBS) was gently shaken in a water bath at $37^{\circ} \mathrm{C}$ for 40 $\min$. Then, the tubes were centrifuged at 2500 $\mathrm{rpm} / \mathrm{min}$ for $15 \mathrm{~min}$. to allow broken membranes and unbroken cells to settle at the bottom. For positive control, or (100\% hemolysis), $500 \mu \mathrm{L}$ of $0.2 \%$ Triton in (PBS) was added to $2.5 \mathrm{ml}$ of $10 \%$ RBC suspension. The supernatant was removed, and the liberated hemoglobin in the supernatant was measured using the spectrophotometric method for absorbance at $540 \mathrm{~nm}$. For negative control, or ( $0 \%$ hemolysis), only $500 \mu \mathrm{L}$ of PBS was added to $2.5 \mathrm{ml}$ of $10 \% \mathrm{RBC}$ suspension. The experiment was done in five replicates and the mean \pm standard deviation was calculated as follow

$\%$ Hemolysis $=$ (Absorbance of the sample/Absorbance of positive control) $\times 100$. 
Erythrocyte hemolysis induced by peroxyl free radical (AAPH) ${ }^{40 \& 42}$

Fresh human blood samples were taken from healthy volunteers being granted permission, non-smokers, with an average age of 25 years. The blood was collected in EDTAcontaining tubes as an anticoagulant, and centrifuged (at $2500 \mathrm{rpm}$ for $10 \mathrm{~min}$, at temperature $\left(20-25^{\circ} \mathrm{C}\right)$. The plasma was washed three times or more (with PBS 10 mmol $\mathrm{pH}=7.4$ ) until plasma and buffy coat removal. The red blood cells suspension (RBC) $(20 \%-\mathrm{v} / \mathrm{v})$ was prepared in (PBS). Mixed 0.1 $\mathrm{ml}$ of $20 \%$ RBC suspension with $0.2 \mathrm{ml}$ of 200 $\mathrm{mM} \mathrm{2,} 20$ - azobis (2-amidinopropane) dihydrochloride (AAPH) solution (in PBS) and $0.1 \mathrm{ml}$ of extract of the plants at concentrations $(1,2,3,4,5) \mathrm{mg} / \mathrm{ml}$ Prepared in (PBS). The reaction mixture was shaken gently $(30 \mathrm{rpm})$ in a water bath at $37^{\circ} \mathrm{C}$ for 3 hours. Then they were centrifuged at $5000 \mathrm{rpm} / \mathrm{min}$ for $10 \mathrm{~min}$. $0.3 \mathrm{ml}$ of supernatant liquid diluted with (0.6 $\mathrm{ml}$ ) of PBS and using the spectrophotometric method for absorbance at $(540 \mathrm{~nm})$. The positive control is AAPH and red blood cell suspension without the plants' extracts. The negative control is PBS and red blood cell suspension. L-ascorbic acid was used as a reference standard. The experiment was done in five replicates and the mean \pm standard deviation was calculated as follow

$\%$ hemolysis inhibition = $\left[\left(\mathrm{AAPH}_{\mathrm{AS}}\right) / \mathrm{AAPH}_{+\mathrm{c}}\right] .100$, where $\mathrm{AS}$ is the absorbance of the sample, and $+c$ is the absorbance of positive control.

\section{RESULTS}

\section{Extraction yield}

The crude dried extracts obtained were nicely aromatized, brown, and the yield percentage of the solid residue weight of $C$. verutum extract was higher than the others plants, followed by $O$. carduiforme extract and A. santolina extract came last in yield percentage, as shown in (Table 2).
Table 2: The yields percentage of solid residue.

\begin{tabular}{|c||c||}
\hline \multicolumn{1}{|c||}{ Plants } & Yield \% \\
\hline \hline Onopordum carduiforme & $13.44 \%$ \\
\hline Centaurea verutum & $15.92 \%$ \\
\hline \hline Achillea santolina & $9.17 \%$ \\
\hline
\end{tabular}

\section{Phytochemical analysis}

Fundamental phytochemical screening results showed that the hydroethanolic extracts of the three plants contain all of the following phytochemical groups; phenols, flavonoids, tannins, coumarins, cardiac glycosides, terpenoids, steroids, and carbohydrates. Whereas no alkaloids or saponins were found (Table 3).

\section{Total phenolic content (TPC)}

The total phenolic content of the examined plants' extracts was calculated according to the equation of calibration curve for gallic acid (Figure 1), $\left(\mathrm{y}=5.9333 \mathrm{x}+0.0324, \mathrm{R}^{2}=0.9988\right)$. The values obtained for the extracts content of total phenols were expressed as mg of GAE/g of plants dry weight. The results range was between $(9.22 \pm 0.412$ and $13.716 \pm 0.431 \mathrm{mg}$ GAE/g DW), and the highest content was recorded by (C. verutum) (Table 4$)$.

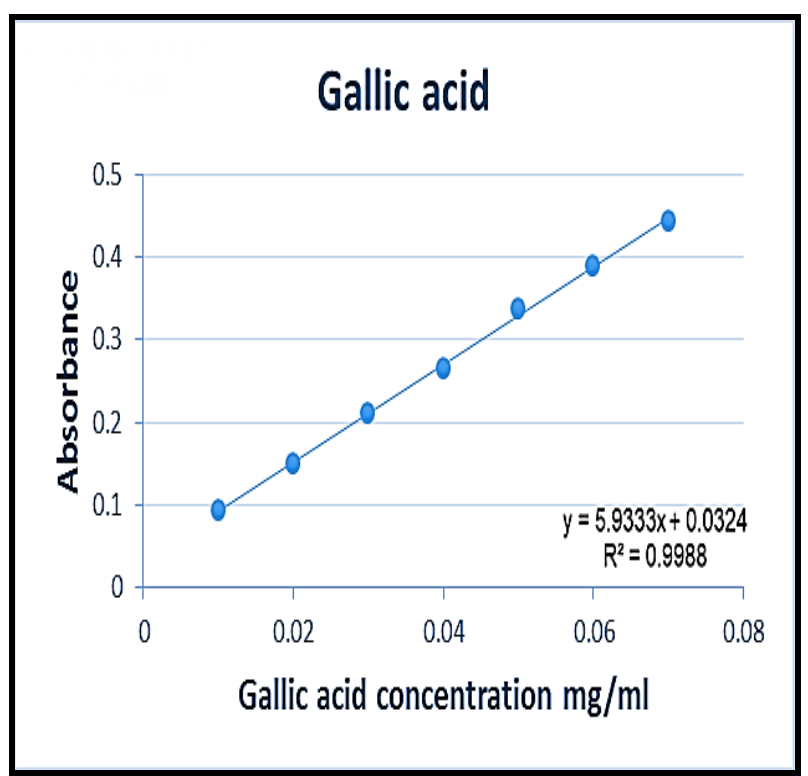

Fig. 1: Calibration curve of Gallic acid for determination of TPC. 
Table 3: Phytochemical screening of various extractives of $O$. carduiforme, Centaurea verutum and Achillea santolina

\begin{tabular}{|c|c|c|c|c|}
\hline Plants constituent & Test/Reagent used & $\begin{array}{l}\text { Onopordum } \\
\text { carduiforme }\end{array}$ & $\begin{array}{c}\text { Centaurea } \\
\text { verutum }\end{array}$ & $\begin{array}{l}\text { Achillea } \\
\text { santolina }\end{array}$ \\
\hline \multirow{2}{*}{ Phenols } & Ferric Chloride & + & + & + \\
\hline & Folin Ciocalteu & + & + & + \\
\hline \multirow{3}{*}{ Flavonoids } & Aluminum chloride & + & + & + \\
\hline & Shinoda test & + & + & + \\
\hline & Pew's Tests & + & + & + \\
\hline \multirow{2}{*}{ Alkaloids } & Dragendroff & - & - & - \\
\hline & Mayer's & - & - & - \\
\hline \multirow{3}{*}{ Tannins } & Ferric chloride & + & + & + \\
\hline & Lead acetate test & + & + & + \\
\hline & Vanillin & + & + & + \\
\hline \multirow{2}{*}{ Saponins } & foam & - & - & - \\
\hline & aromatic aldehydes & 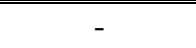 & - & - \\
\hline Coumarins & fluorescence & + & + & + \\
\hline \multirow{2}{*}{ Cardiac Glycosides } & Killer-Killiani & + & + & + \\
\hline & Kedde & + & + & + \\
\hline Terpenoids & Salkowski test & + & + & + \\
\hline Steroids & Libermann Burchard's & + & + & + \\
\hline \multirow{2}{*}{ Carbohydrates } & Molisch's & + & + & + \\
\hline & Fehling's & + & + & + \\
\hline $\begin{array}{l}\text { Cyanogenic } \\
\text { Glycosides }\end{array}$ & Picrate paper & - & - & - \\
\hline
\end{tabular}

+ Present, - absent

Table 4: Total phenol content (TPC) in the plants extracts.

\begin{tabular}{|c||c|c||}
\hline Plants & TPC $(\mathrm{mg} \mathrm{GAE} / \mathrm{g} \mathrm{DW})$ & TPC (mg GAE/g Extract) \\
\hline \hline Onopordum carduiforme & $10.301 \pm 0.351$ & $84.906 \pm 2.892$ \\
\hline Centaurea verutum & $13.716 \pm 0.431$ & $97.257 \pm 2.610$ \\
\hline \hline Achillea santolina & $9.193 \pm 0.412$ & $105.675 \pm 4.740$ \\
\hline
\end{tabular}

GAE: gallic acid equivalents

Each value is the average of three replicates \pm standard deviation

Total flavonoids content (TFC)

The total flavonoid content of the plants' extracts was determined using the aluminum chloride colorimetric method, and calculated according to the equation of calibration curve for rutin (Figure 2), $\left(y=14.682 x+0.0213, R^{2} 0.9992\right)$. The results were expressed as mg of RUE/g of plant's dry weight. While (C. verutum) scored the highest content, the whole results ranged between $(2.224 \pm 0.346$ and $8.958 \pm 0.216 \mathrm{mg} \mathrm{RUE} / \mathrm{g}$ DW). (Table 5). 
Table 5: Total flavonoids contents (TFC) in the plants extracts.

\begin{tabular}{|c||c||c||}
\hline Plants & TFC $(\mathrm{mg}$ RUE/g DW) & TFC (mg RUE/g Extract) \\
\hline \hline Onopordum carduiforme & $2.224 \pm 0.346$ & $17.097 \pm 0.927$ \\
\hline \hline Centaurea verutum & $8.958 \pm 0.216$ & $62.211 \pm 1.499$ \\
\hline \hline Achillea santolina & $5.183 \pm 0.231$ & $59.578 \pm 2.65$ \\
\hline
\end{tabular}

RUE= Rutin equivalents

Each value is the average of three replicates \pm standard deviation

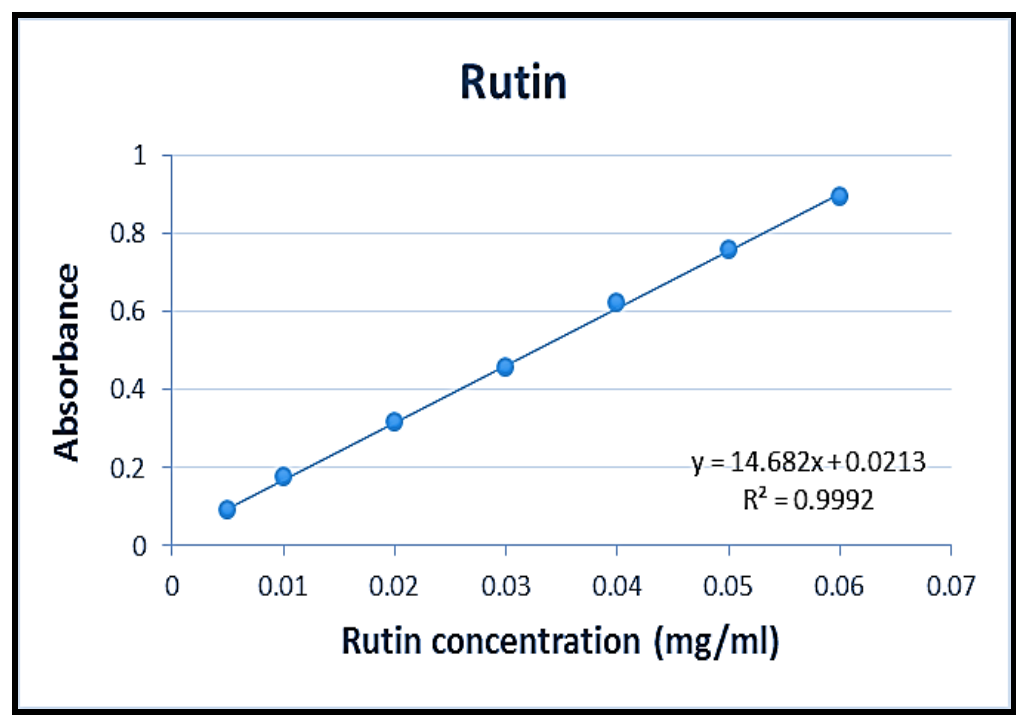

Fig. 2: Calibration curve of Rutin for determination of TFC

\section{Hemolysis test}

A hemolytic assay experiment was followed to evaluate the effect of $O$. cadruiforme, $C$. verutum and $A$. santolina extracts on red blood cells. The hemolysis test result showed that the plants' extracts have caused hemolysis percentages that are close to the negative control effect (Table 6, Figure 3). There was a clear relationship between the increased plant concentrations and the measured absorbance values, which represent the hemolysis action. At the highest concentrations used $(4,5 \mathrm{mg} / \mathrm{ml})$ the hemolysis percentage was slightly more observed, but still not statistically significant as compared to the negative control. Thus, we can consider these plants' extracts as safe and nontoxic to red blood cells in the used concentrations.

Table 6: The percentages of hemolytic effect by $O$. carduiforme, $C$. verutum , A. santolina extract and Negative control:

\begin{tabular}{|c|c|c|c|c|c|}
\hline \multirow{3}{*}{ Plants' extracts } & \multicolumn{5}{|c|}{ Hemolysis\% } \\
\hline & \multicolumn{5}{|c|}{ Concentration (mg\ml) } \\
\hline & 1 & 2 & 3 & 4 & 5 \\
\hline O. carduiforme & $7.216 \pm 2.13$ & $7.518 \pm 2.04$ & $7.772 \pm 2.14$ & $8.15 \pm 2.00$ & $9.44 \pm 1.89$ \\
\hline C. verutum & $7.034 \pm 2.14$ & $7.364 \pm 2.16$ & $8.014 \pm 2.05$ & $8.998 \pm 1.74$ & $10.236 \pm 1.78$ \\
\hline A. santolina & $6.77 \pm 2.51$ & $7.088 \pm 2.76$ & $8.062 \pm 3.07$ & $8.18 \pm 2.78$ & $9.228 \pm 2.90$ \\
\hline $\begin{array}{l}\text { Negative control } \\
\text { control (PBS } \\
\text { buffer) }\end{array}$ & \multicolumn{5}{|c|}{5.948} \\
\hline
\end{tabular}

Each value is the average of five replicates \pm standard deviation 


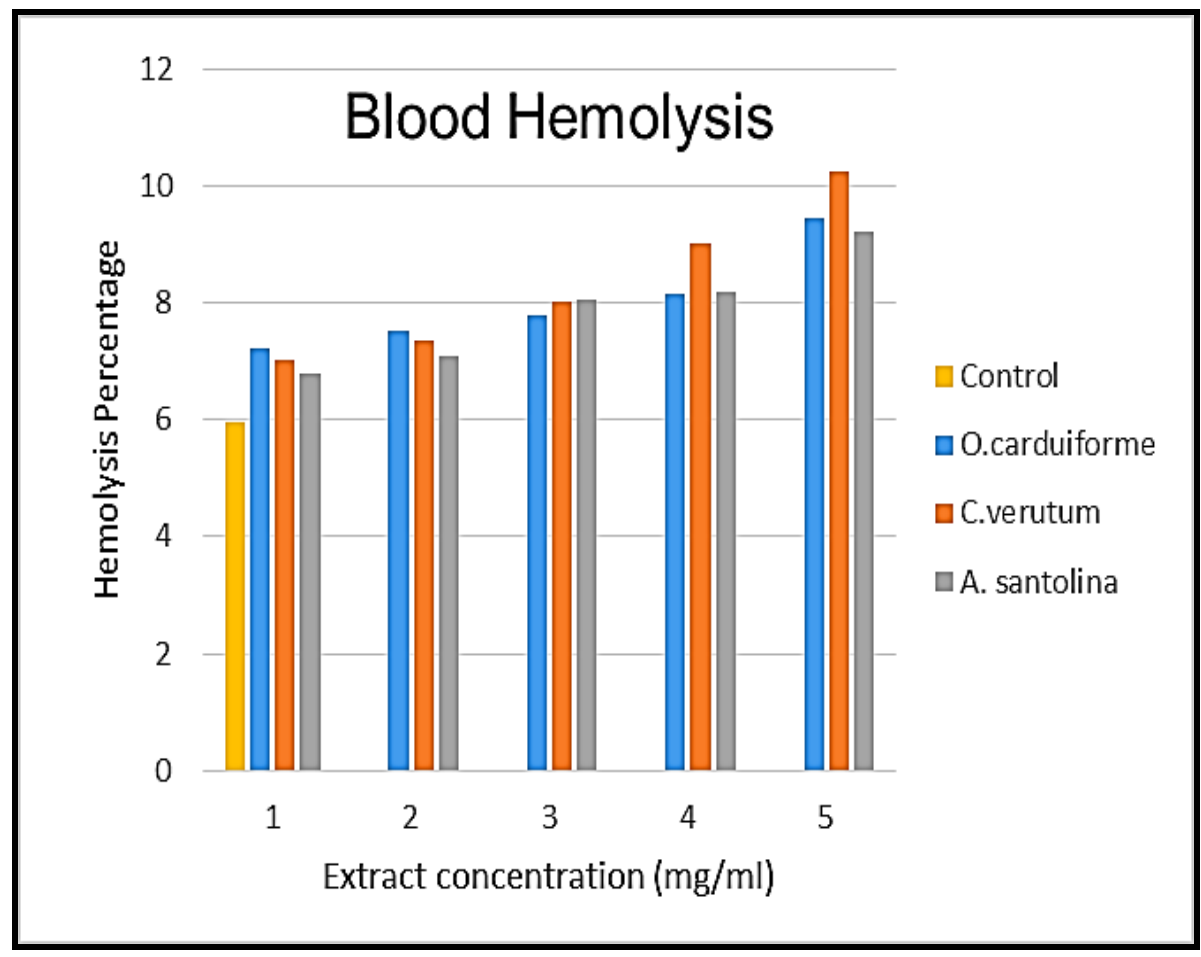

Fig. 3: The percentages of Hemolysis blood of plants extract in comparison with negative control

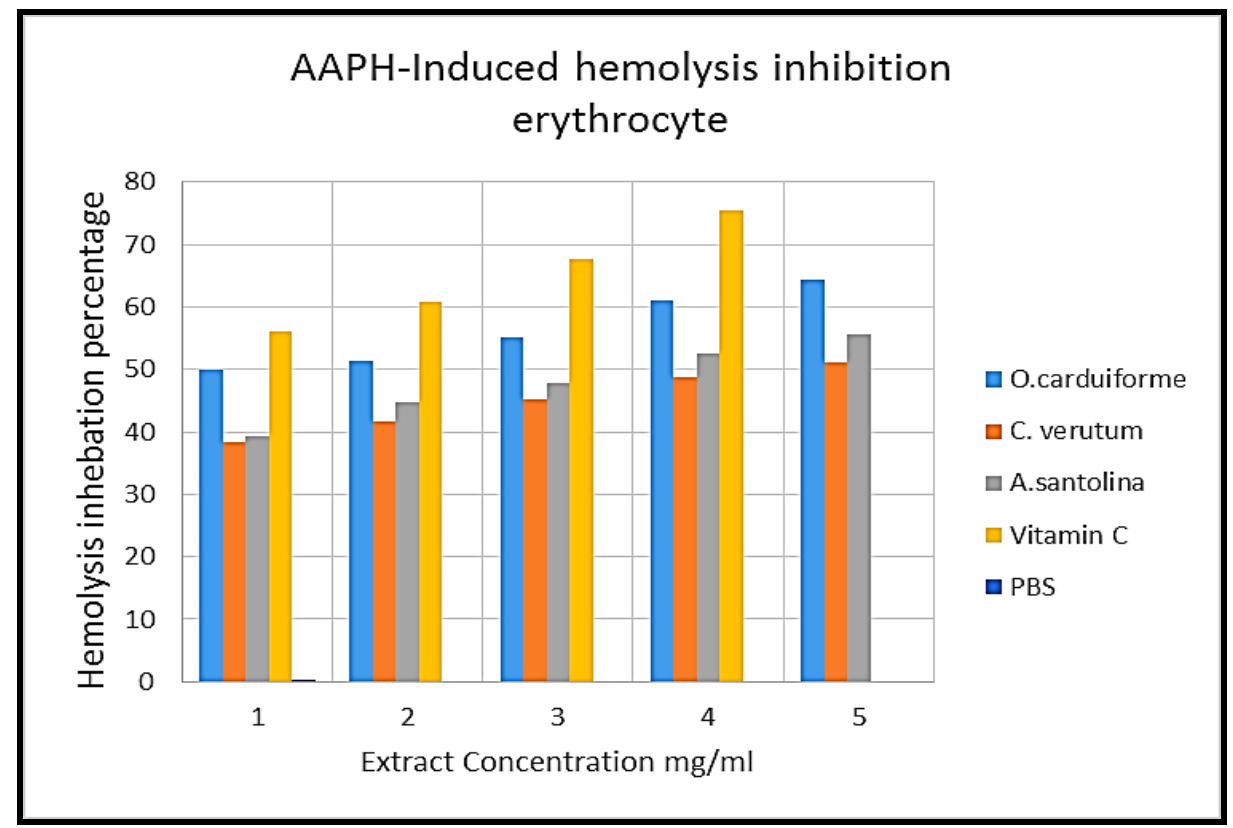

Fig. 4: Hemolysis inhibition (\%) of the plants extract extracts in comparison with vitamin C.

\section{Erythrocyte hemolysis induced by peroxyl free radicals (AAPH)}

The oxidative hemolysis in erythrocytes induced by AAPH (2,2- azobis 2amidinopropane dihydrochloride) has been by oxidative stress in the erythrocyte membranes. extensively studied as a model for peroxidative damage in bio-membranes. This study evaluates the ability of studied the plants' extracts to reduce the damage caused 
Table 7: The percentages of Protection hemolysis\% effect by $O$. Carduiforme, C. verutum, A. santolina extract and Vitamin C

\begin{tabular}{|c|c|c|c|c|c|}
\hline \multirow{3}{*}{ Plants' extracts } & \multicolumn{5}{|c|}{ Protection hemolysis\% } \\
\hline & \multicolumn{5}{|c|}{$\begin{array}{l}\text { Concentration }(\mathrm{mg} \backslash \mathrm{ml}) \\
\end{array}$} \\
\hline & 1 & 2 & 3 & 4 & 5 \\
\hline O. carduiforme & $49.988 \pm 20.98$ & $51.416 \pm 22.54$ & $55.158 \pm 21.70$ & $61.03 \pm 20.92$ & $64.332 \pm 20.45$ \\
\hline C. verutum & $38.358 \pm 198$ & $41.636 \pm 14.98$ & $45.232 \pm 11.26^{*}$ & $48.7 \pm 11.64 *$ & $51.148 \pm 4.96$ \\
\hline A. santolina & $39.396 \pm 19.64$ & $44.752 \pm 19.74$ & $47.87 \pm 6.57 *$ & $\begin{array}{c}52.45 \pm 20.39 \\
*\end{array}$ & $55.702 \pm 8.95$ \\
\hline $\begin{array}{c}\text { Vitamin C } \\
\text { (positive } \\
\text { control) }\end{array}$ & $56.106 \pm 7.68$ & $60.744 \pm 7.38$ & $67.76 \pm 8.07 *$ & $75.84 \pm 6.21 *$ & 一 \\
\hline $\begin{array}{l}\text { PBS (Negative } \\
\text { control) }\end{array}$ & \multicolumn{5}{|c|}{$0.062 \pm 0.024$} \\
\hline
\end{tabular}

*Express the presence of a significant difference with Vitamin $\mathrm{C}$ at Significant differences at $(\mathrm{P}<$ $0.05)$

Each value is the average of five replicates \pm standard deviation

The results showed that all of the plants' extracts are effective as they can inhibit oxidative hemolysis (Figure 4). The percentage range that represents the reduction of oxidative hemolysis was between $(38.358 \pm 19.80 \%$ and $64.332 \pm 20.45 \%)$. O. carduiforme showed the highest protective effect against erythrocytes oxidative hemolysis $(49.98 \%$ at $1 \mathrm{mg} / \mathrm{ml})$ and $(64.32 \%$ at $5 \mathrm{mg} / \mathrm{ml})$. While $\mathrm{C}$. verutum has the lowest protective effect against erythrocytes hemolysis $(51.14 \%$ at $5 \mathrm{mg} / \mathrm{ml})$. The percentages of hemolytic effect for all the plants' extracts were significantly higher than the negative control. However, the inhibition percentage of the standard L-ascorbic acid on hemolysis of red blood cells was (56.106 \pm 7.68 at $1 \mathrm{mg} / \mathrm{ml}$ ). While at $5 \mathrm{mg} / \mathrm{ml} \mathrm{L-ascorbic}$ acid showed erythrocytes hemolysis and no protective effect. Significant differences between extract and positive control are represented in (Table 7).

\section{DISCUSSION}

\section{Phytochemical screening}

The phytochemical analysis of plants is an essential process in each phytochemical study. The chemical compounds that have been found in the studied plants are known to provide important biological activities, which gives these species their medical importance.
Phytochemical screening results showed that the hydroethanolic extract contains phenolic compounds, flavonoids, tannins, coumarins, cardiac glycosides, terpenoids, steroids, and carbohydrates. The results of $O$. carduiforme were similar to the results of another study of $O$. macrocephalum which have been studied in Aleppo University too. With one exception, that $O$. macrocephalum does not have coumarins ${ }^{16}$. While another phytochemical study of Onopordum acanthium L. showed that it has coumarins in its aerial parts ${ }^{43}$. The results for $C$. verutum were consistent with the previous study of Centaurea cineraria $L$. as both species have carbohydrates, phenols, tannins, and flavonoids, but do not have saponins $^{44}$. However, Centaurea ammocyanus has a little amount of saponins $^{45}$. Achillea santolina contains phenolic and flavonoids compounds, and this matches what Al-Snafi has reported in his results $^{46}$. Tannins, steroids, and terpenoids were found in Achillea tenuifolia $L A m$ extract $^{47}$. However, these agreements/disagreements among studies and the plants included are typically normal, and may be due to the difference in plant parts used as raw material, the solvent used for extraction, or the extraction procedure ${ }^{31}$ 


\section{Total phenolic content}

Phenols form the largest group of plant secondary metabolites widespread in nature, and they are very important compounds of medicinal plants. At first, it should be noticed that the phenolic content in one plant species, in general, is affected by several parameters, such as the solvent used to prepare the plant extract, the environmental conditions of each geographical area, and the collecting time of plant samples ${ }^{44}$.

The highest phenolic content in this study was observed in C. verutum (13.716 \pm 0.431 mg GAE/g DW), followed by $O$. carduiforme (10.301 $\pm 0.351 \mathrm{mg}$ GAE/g DW), and the lowest was in A. santolina $(9.193 \pm$ $0.412 \mathrm{mg} \mathrm{GAE} / \mathrm{g} \mathrm{DW}$ ).

The result for phenolic content of $O$. carduiforme in this study exceeds the ones of Sharif et al of other Onopordum species from Syria, AqME* extracts of Onopordum macrocephalum where TPC was reported as $(8.15 \pm 0.35$ and $8.87 \pm 0.19 \mathrm{mg} \mathrm{GAE} / \mathrm{g} \mathrm{DW})$ for floral parts and vegetative parts respectively ${ }^{14}$. The TPC of $O$. carduiforme was $(84.906 \pm 2.89 \mathrm{mg}$ GAE$/ \mathrm{g}$ extract) which is slightly lower than Onopordum acanthium $(89.3 \pm 0.13 \mathrm{mg} \mathrm{GAE} / \mathrm{g} \text { extract })^{48}$. The TPC of Aq extract of Centaurea cyanus $L$. was $(5.65 \mathrm{mg} \mathrm{GAE} / \mathrm{g} \mathrm{DW})^{49}$ while in another study in Syria of AqME extract of $C$. cineraria the TPC was $(41.12 \pm 0.6 \mathrm{mg}$ GAE$/ \mathrm{g}$ extract). Therefore, it can be concluded that the species of Centaurea in our study have a higher content of phenols ${ }^{44}$.

Achillea santolina has the lowest content of phenols in this study among the three Asteraceae plants $(105.675 \pm 4.74 \mathrm{mg} \mathrm{GAE} / \mathrm{g}$ extract). However, it exceeds other species like Achillea sivasica whose TPC was $(34.5 \pm$ 1.7 and $51.1 \pm 0.8 \mathrm{mg} \mathrm{GAE} / \mathrm{g}$ extract) for herbal and floral parts respectively ${ }^{50}$. In addition, our results are in resemblance with Ardestani's, which showed TPC of $A$. santolina as $(104.66 \pm 4.39 \mathrm{mg} \quad \mathrm{GAE} / \mathrm{g}$ extract $)^{51}$. These differences in the contents might be because of polar phenolic hydroxyl group/s substitutions in phenol structure or their high extraction tendency into polar solvents. However, ethanol $70 \%$ solvent seems to possess higher concentrations of bioactive phenol compounds, and this could be related to polarity that tend to dissolve easily in such solvent ${ }^{31 \& 52}$.

\section{Total flavonoids content:}

Flavonoids which occur both in the free situation and as glycosides, are the largest group of naturally occurring phenols. More than 2000 of these compounds are well-known and have already been isolated, 500 of them exist in the free state ${ }^{53}$. The highest flavonoid content in this study was observed in $C$. verutum $(8.958 \pm 0.216 \mathrm{mg}$ RUE/g DW), followed by A. Santolina $(5.183 \pm 0.231 \mathrm{mg}$ RUE/g DW) and the lowest was found in $O$. carduiforme $(2.224 \pm 0.346 \mathrm{mg}$ RUE/g DW). The Flavonoids content of $O$. carduiforme was lower than Onopordum macrocephalum floral parts and vegetative parts, where TFC was reported as $(14.35 \pm 0.0 .19$ and $12.35 \pm 0.61$ $\mathrm{mg}$ RUE/g DW) respectively ${ }^{14}$. The TFC of Centaurea verutum was $(62.211 \pm 1.49 \mathrm{mg}$ $\mathrm{RUE} / \mathrm{g}$ extract), and thus it is higher than other species; $C$. kotschyi var. persica and $C$. tchihacheffii, where the TFC was $(5.76 \pm 1.65$, $3.06 \pm 0.55 \mathrm{mg}$ RUE/g extract) respectively ${ }^{54}$.

Finally, the TFC of Achillea santolina was $(5.183 \pm 0.231 \mathrm{mg}$ RUE/g DW), and A. schurii extract was $(38.61 \pm 2.39 \mathrm{mg} \mathrm{RUE} / \mathrm{g} \mathrm{DW})^{55}$. These figures variation may be related to the polarity of solvents. Interestingly, it is important to emphasize that the TFC is lower than TPC, supporting the fact that flavonoids belong to the phenols major group. Moreover, the differences in total phenols and flavonoids content among species could be due to several intrinsic and extrinsic factors, such as the genetic potential of individual species for polyphenol biosynthesis, the environment and maturation stage of each plant may also be critical in this aspect ${ }^{39 \& 52}$.

\section{Hemolysis test}

A toxicity test is so important in investigating the effect of natural compounds on the red blood cell membrane; hemolytic activity assessment is useful for this purpose. This test has been widely used as a model for studying the interaction of drugs with cellular membranes. It presents a direct indication of the toxicity of injectable formulations ${ }^{44}$. 
The percentage range of hemolysis that was affected by the plants was between $(6.77 \pm$ 2.51 and $10.236 \pm 1.78 \%)$. Statistically, no significant effect was found between red blood cells that were treated with the extracts compared to the negative control.

It is interesting also to note that, the color of the extract itself in its highest concentrations (4 - 5) $\mathrm{mg} / \mathrm{mL}$ might have caused an additional increase in the measured absorbance value against the colorless physiological solution. Where the percentage of hemolysis is calculated as a result of the division: absorption of the sample containing the extract/absorption of the positive control (represents 100\% hemolysis).

Some of the studies about the Centaurea genus showed that hemolysis percentage was $4.84 \pm 0.9 \%$ of $C$. cineraria at $4000 \mu \mathrm{g} / \mathrm{ml}$ and this value was considered as not toxic on $\mathrm{RBC}^{44}$. Another Centaurea specie $C$. ammocyanus showed safe application without any significant difference compared to negative control in low concentrations (100$500 \mu \mathrm{g} / \mathrm{ml}$ ), although this specie contains a little amount of saponins. However, at higher concentrations $(1000-3000 \mu \mathrm{g} / \mathrm{ml})$ the hemolysis percentage increased. Other plants from the Asteraceae family which contain little amount of saponons, such as Sonchuso leraceus

and Matricaria chamomilla, possesed a low hemolytic effect on RBC in both methanolic and aqueous extracts ${ }^{57 \& 58}$. The methanolic and aqueous extracts of Silybum marianum also contain saponins, and the hemolysis percentage at $1000 \mu \mathrm{g} / \mathrm{ml}$ was $(42.7 \pm 0.66,36.5 \pm 0.67 \%)$ respectively. To sum up, higher damage in RBC membrane is expected along with the higher presence of saponins. Fortunately, the Phytochemical screening (Table 2) shows that all of the three plants in this research do not contain saponins. However, some studies considered that plants' extracts are safe and do not show toxicity on red blood cells when the hemolysis percentage is less than $10 \%{ }^{59}$.

Saponins have potent toxicity by inducing hemolysis of red blood cells. The release of hemoglobin from erythrocytes is a result of changes in cells' membrane permeability. This is expected to be influenced by the affinity of the aglycone to cholesterol in cell membranes. The type of saponins and the quantitative content of the plant may cause different levels of hemolytic activity ${ }^{56}$. It should be noted that saponins are surface-active agents, with soaplike properties and can be detected by their ability to cause foaming or their ability to lyse blood cells. Another major reason for hemolysis is oxidative stress. The oxidative damage can affect proteins and lipids within the erythrocyte membrane and contribute to some hemoglobinopathies and lipid peroxidation $^{1 \& 38}$. In this study, the plants' extracts contain phenols, flavonoids, and tannins which are known to have antioxidant properties, so it can be considered that the studied plants are good protective agents against oxidative stress by their polyphenols content.

\section{Erythrocyte hemolysis induced by peroxyl free radicals (AAPH)}

Several tests are used in modern research to evaluate the extracts inhibition activity of hemolysis, such as the assessment by using hypotonic solutions, the assessment by using $\mathrm{H}_{2} \mathrm{O}_{2}$, or by peroxyl free radicals.

Centaurea cineraria and Centaurea ammocyanus have provided a significant protection against $\mathrm{H}_{2} \mathrm{O}_{2}$ induced oxidative damage in human erythrocytes at high concentrations $(1000-4000 \mu \mathrm{g} / \mathrm{ml})$ and $(1000$ $3000 \mu \mathrm{g} / \mathrm{ml}$ ) respectively ${ }^{45 \& 48}$.

Turkish Achillea specie which were used in traditional medicine were also studied. The results showed that all infusions of Achillea species were found to be protective against lipid peroxidation (LPO) levels of erythrocytes and leucocytes counter to $\mathrm{H}_{2} \mathrm{O}_{2}$ induced oxidative damage. In that study, Achillea millefoliums sppannonica and Achillea falcata (TFC \% $0.250 \pm 0.080$, ТPC $\% 157.78 \pm 1.36 \mathrm{mg} \mathrm{GA}$ eq/l) had the lowest LPO levels on erythrocytes.

Achillea nobilissubspsipylea and Achillea setacea (TFC\% $0.096 \pm 0.015$ TPC\% $121.81 \pm$ $1.82 \mathrm{mg}$ GA eq/l) showed the highest protective effects on leucocytes ${ }^{60}$. Sonchuso leraceus, Matricaria chamomilla, and Silybum marianum from the Asteraceae family have 
efficacy as an antioxidant via the inhibition of $\mathrm{H}_{2} \mathrm{O}_{2}$ induced hemolysis ${ }^{56-58}$.

In this study, the assay for erythrocyte hemolysis was mediated by peroxyl free radical which is AAPH (2,2-azobis 2-amidinopropane dihydrochloride). AAPH is a peroxyl radical initiator that generates free radicals by its thermal decomposition, and then it attacks the erythrocytes to induce the oxidation chain of the lipids and proteins, disturbing the membrane structure and eventually leading to hemolysis ${ }^{42}$.

The range of hemolysis inhibition percentage was between $(38.358 \pm 19.80$ and $64.332 \pm 20.45 \%$ ), these values are similar to flowers extracts of Cosmos sulphureus plant (Asteraceae family), which ethyl acetate and acetone extracts were tested for their antihemolytic activity $(30.12 \pm 0.12$ to $65.48 \pm$ $0.26 \%)$ and $(25.78 \pm 0.10$ to $62.92 \pm 0.25 \%)$ respectively. These values have a correlation proportional to the gradual increase in the concentrations used. The result of the total phenols and flavonoids content showed that the extracts that contain a good amount of these phytochemicals, are more likely to show antioxidant properties. This difference in activity is related to variations in the quantity and chemical structure of phenols and flavonoids. As well as the substitution of hydroxyl groups on the phenolic aromatic ring, their hydrogen donor ability and forming resonance-stabilized phenoxyl radicals, as the antioxidant activity increases by increasing the degree of hydroxylation ${ }^{52}$. In this test, we used ascorbic acid as a positive control because it is well-known as an antioxidant agent. The results showed that the percentage of ascorbic acid protection of hemolysis activity at concentrations $(1.2 .3,4 \mathrm{mg} / \mathrm{ml})$ was between $(56.106 \pm 7.68$ and $75.84 \pm 6.21 \%) \%$, but, at 5 $\mathrm{mg} / \mathrm{ml}$ concentration, erythrocyte hemolysis was occurred, or its antioxidant efficacy was decreased, which suggested that, vitamin $\mathrm{C}$ might have a pro-oxidant activity. This is confirmed by several studies, which reported that there are some conditions when vitamin $\mathrm{C}$ can act as pro-oxidant, such as its high concentrations, the redox potential of the cellular environment (oxidises/redosis), and the presence or absence of transition metals. The pro-oxidant activity of vitamin $\mathrm{C}$ could be due to a potential reaction between vitamin $\mathrm{C}$ and transition metal ions such as free iron so that promote their reduction, increase $\mathrm{H}_{2} \mathrm{O}_{2}$ production and consequently $\mathrm{OH}^{*}$ formation of leading to oxidative damage to biomolecules or may interact with erythrocytes causing lipid peroxidation of the membrane, oxidation of hemoglobin and thus hemolysis ${ }^{44 \& 45,61 \& 62}$.

\section{Conclusions}

The results of this study of three plants of the Asteraceae family from Syrian flora conclude that; Onopordum carduiforme, Centaurea verutum, and Achillea santolina are rich in phytochemical compounds especially phenols and flavonoids. The highest one in the total phenols and flavonoids contents was Centaurae verutum. All of the plants' extracts have very low hemolytic toxicity against human erythrocytes, have significant protective activity against lipid peroxidation, and could prevent oxidative damage induced by AAPH in normal human erythrocytes. The most protective extract was Onopordum carduifome. This study supports the theory that these plants can be a good source of natural antioxidants, that can be used in drugs industry as natural sources of antioxidants compounds in the case of oxidative diseases.

\section{Acknowledgements}

We greatly acknowledge the research laboratory, Department of PharmacognosyAleppo University- Syria, for the technical and financial support of the research.

\section{REFERENCES}

1. S. Rashidpour, F. Zahedipour, G. Karimi and K. Jamialahmadi, "Protective effects of osthole against free radical-induced hemolysis of erythrocytes", Pharm Sci, 27(1), 56 - 62 (2021).

2. J. Barnes, A. Anderson and D. Phillipson, "Herbal Medicines", Pharmaceutical Press, $3^{\text {th }}$ Edn., 2007, p. 4.

3. A. Chevallier, "Alternative Medicine", Medicinal Herbs and Natural Plants", Academia, $1^{\text {st }}$ Edn., 2005, pp.1-337. 
4. M. Tadesse, "How to study the Asteraceae (Compositae) with special reference to the Asteraceae of fee", Ethiop J Biol Sci., 13, 91-101 (2014).

5. S. Bessada, J. Barreira, M. Beatriz and P. Oliveira, "A review: Asteraceae species with most prominent bioactivity and their potential applications", Ind Crop Prod, 76 (1), 604-615 (2015).

6. P. Mouterde, "Nouvelle Flore Du Liban Et De La Syrie", Dar El-Mashreq, Lebanon , $2^{\text {nd }}$ Edn., 2005.

7. A. Takhtajan, "Flowering Plants", Springer Science \& Business Media B.V, $2^{\text {nd }}$ Edn., 2009, p. 498.

8. N. Feinbrun-dothan, "Flora palaestina, part three-text Ericaceae to compositae," Jerusalem Academic Press, Israel, 1978, pp. $1-501$.

9. A. Al-Snafi, "Constituents and pharmacology of Onopordum acanthium", IOSR J Pharm, 07-14 (2020).

10. M. Misra, "Traditional plants to modern medicine and methods for ex situ conservation of native medicinal plants ", J Med Plant Res, 3 (9), Editorial section (2009).

11. M. Obeidat, "Antimicrobial activities from extracts of seven medicinal plant species against multidrug-resistant bacteria and fungi", J Pharmacog Phytother, 10 (3), 4555 (2018).

12. H. Salehabadi, K. Khajeh, B. Dabirmanesh, M. Biglar and M. Amanlou, "Evaluation of Angiotensin Converting Enzyme inhibitors by SPR biosensor and Theoretical Studies", Enzyme Microb Technol, 120, 117-123 (2018).

13. N. Sharifi, E. Souri, S. Ali ziai, G. Aming and $M$ Amanlou, "Discovery of new angiotensin converting enzyme (ACE) inhibitors from medicinal plants to treat hypertension using an in-vitro assay", DARU J Pharm Sci, 21 (74), 1-8 (2013).

14. S. Sharif, A. Kitaz and R. Al-Kayali, "A Phytochemical Study of Some Species of Onopordon Wildly Grown in Syria and Investigation of Antibacterial Activity invitro", Master Thesis, Faculty Of Pharmacy, Aleppo University, (2015).

15. E. Valizadeh, F. Zonous, A. Zand, S. Shabazi and A Malekian, "Evaluation of Antioxidant Potentials of Extracts of Cotton
Thistle (OnopordumLeptolepis DC.) Obtained by Various Solvents", Aust J Crop Sci, 5 (10), 1163-1166 (2011).

16. S. Sharif, A. Kitaz and R. Kayali, "TLC Screening and Evaluation of Antioxidant. Antibacterial Activity of OnopordonMacrocephalum by Bioautography Method", Iran J Pharm Sci, 12 (2), 1-8 (2015).

17. T. Fleming, J. Gruenwald, T. Brendler and C Jaenicke, "PDR for Herbal Medicines", Medical Economics Company, Montvale, $2^{\text {nd }}$ Edn., 2000, pp. 1-1110

18. M. Boğa, H. Alkan, A. Ertaş, E. Varhan Oral, M. Yılmaz, Yeşily, et al., "Phytochemical profile and some biological activities of three Centaurea species from Turkey", Trop J Pharm Res, 15 (9), 18651875 (2016).

19. A. Idris, A. Aliyu and A. Oyewale, "Phytochemical Screening and Antibacterial Activity of Centaurea senegalensis growing in Nigeria", J Appl Sci Environ Manage, 23 (6), 1087-1092 (2019).

20. A. Duran, N. Uslu, B. Doğan, M. Özcan and M. Çelik M, "Antioxidant Activity and Phenolic Contents of 30 Selected Medicinal Plants", J Agroaliment Processes Technol, 21 (2), 136-141 (2015).

21. A. Alachkar, A. Jaddouh, M. Elsheikh, A. Bilia and F. Vincieri, "Traditional Medicine in Syria: Folk Medicine in Aleppo Governorate", Nat Prod Commun, 6 (1), 79-84 (2011).

22. J. Patocka, Z. Navratilova, "Achillea fragrantissima Pharmacology Review", Clin Oncol, 4, 1601 (2019).

23. A. Hatem, W. Lara, B. Safaa, N. Nabil and A. Nelly, "Antimicrobial Activity of Essential Oils from Achillea fragrantissima (Forssk.) Sch.Bip (Asteraceae) Growing Wild in North Bekaa", Int J Eng Sci Res Technol, 7 (5), 115-124 (2018).

24. M. Salem, R. Gaafar, R. Mohasseb and M. Abd-Elbaseer, "In vitro Apoptotic effects of the medicinal plants Achillea santolina and Raphanus sativus extracts on different cancer cell lines", IJCBR, 2 (1), 1-10 (2019).

25. S. Asgary, H. Naderi, N. Sarrafzadegan, N. Mohammad ifard, S. Modtafavi and

26. R. Vakili, "Antihypertensive and Antihyperlipidemic Effects of Achillea 
wilhelmsii", Drugs Exp Clin Res, 26 (3), 89-93 (2000).

27. L. Faisal, A. Inayat, M. Nabi, W. Hayat, M. Sajid Khan and W. Iqbal, "Screening of Achillea santolina For Anti-diabetic Activity And Its Comparison With Caralluma tuberculate", Professional Med J, 27 (7), 1414-1419 (2020).

28. A. Dakah and M. Maarrouf, "Antileishmanial and Antibacterial Activity of Essential Oils of Medicinal Plant Achillea santolina L", Online J Biol Sci, 19 (1), 69-76 (2019).

29. A. Alupului and V. Lavric, "Ultrasound Extraction of Active Principles with Hypoglycaemic Activity from Medicinal Plants", Chem Eng Transact, 14, 83-90. (2008).

30. H. Zhen li, Y. Lantan, Z. Jun zhang, Y. Yao xia, X. Jun li, L. Xia cui, et al., "Optimization of ultrasound-assisted extraction of procyanidins from perilla seed hull and their antioxidant activities in vitro", Food Sci Technol, 39 (2), 378-387 (2019).

31. K. Pobiega, K. Kras'niewska and D. Derewiaka, "Comparison of the antimicrobial activity of propolis extracts obtained by means of various extraction methods", Food Sci Technol, 56 (12), 5386-5395 (2019).

32. P. Tiwari, B. Kumar, M. aur, G. Kaur and H Kaur, "Phytochemical screening and Extraction: A Review", Int Pharm Sci, 1 (1), 98-106 (2011).

33. D.H. Tejavathi and D.R. Jayashree, "Phytochemical Screening of Selected Medicinal Herbs Inoculated with Arbuscukar mycorrhizal fungi", IJBPAS, 2 (11), 2090 - 2106 (2013).

34. J. Thangi, H. Ashwini and K. G Singh, "Qualitative and Quantitative Phytochemical Analysis of Ethanomedicinal Folklore plant Clerodendrum colebrookianum", J Global Biosciences, 5 (1), 3559-3566 (2016).

35. C. Anowi, A. Nedosa, A. Onyegbule and C. Eze, "Preliminary Phytochemical Studies and Evaluation of Antimicrobial Property of the Methanol Extract of the Roobark of Ritchiea longipedicellata Gilg Family Capparidacaea", J Pharmacogn Phytochem, 1 (6), 6-13 (2013).
36. J. Dahanayake, P. Perera, P. Galappatty, H. Perera and L. Arawwawala L, " Comparative Phytochemical Analysis and Antioxidant Activities of Tamalakyadi Decoction with Its Modified Dosage Form", Evid Based Complement Altern Med, 6037137 (2019).

37. $\mathrm{H}$. Monaje and H. Agha, "Practical Chemistry to Extract", Damascus University publication, Syria, practical part, $2^{\text {nd }}$ Edn., 1997.

38. I.L. Ibrahim, M. Musah, M.Z. Dagaci, S.H. Mohammed, H.F. Baba, M.T. Umar et. al, "Phytochemical Screening, Mineral Determination and Antimicrobial Screening of The Leaves Extracts of Piliostigmathonnongii (Matured And Young) Leaves", AJAFS, 2 (1), 15-27 (2019).

39. J. B. Harborne, "Phytochemical Methods a Guide to Modern Techniques of Plant Analysis", Chapman and Hall, $1^{\text {st }}$ issued, 1980, p. 194.

40. S. Milan. Stanković, "Total Phenolic Content, Flavonoid Concentration and Antioxidant Activity Marrubium peregrinum L. Extracts", Kragujevac J Sci, 33, 63-72, (2011).

41. W. Alsheikh, A. Kitaz and G. Sabbagh, "A Comparative Phytochemical Study of the Two Cistus Species Wildly Grown in Syria and Investigation of Antioxidant Activity in-vitro ", Master Degree, Faculty of Pharmacy, Aleppo University, (2016).

42. A. Luis, L. reitenfeld, S. Ferreira, P. Duarte and F. Domingues, "Antimicrobial, antibiofilm and cytotoxic activities of Hakea sericea Schrader extracts", Pharmacogn Mag, 10 (3), 6-13 (2014).

43. L. Barros, M. Ferreira, B. Queiro's, I. Ferreira and P. Baptista, "Total phenols, ascorbic acid, b-carotene and lycopene in Portuguese wild edible mushrooms and their antioxidant activities", Food Chem, 103 (2007), 413-419 (2006).

44. E. Garsiya, D. Konovalov, A. Shamilov, M. Glushko and A. Orynbasarova, Traditional Medicine Plant, Onopordum acanthium L. (Asteraceae), Chemical Composition and Pharmacological Research", Plants, 8(2) (2019).

45. R. Joujeh, "Phytochemical and Biological Study of Centaurea Cineraria L. Cultivated 
in syria, Bull Pharm Sci, 43 (2), 141-147 (2020).

46. R. Joujeh, S. Zaid, S. Mona, Reduction of oxidative stress of normal and G6PD enzyme-deficient human erythrocytes by Centaureaa mmocyanus extract (in vitro study), Pharm Sci Asia., 47 (2),113-120 (2020).

47. A. Al-Snafi, "Chemical Constituents and Pharmacological Activities of Milfoil (Achilleasantolina). A Review", Int J Pharm Tech Research, 5 (3), 1373-1377 (2013).

48. A. Manayi, T. Mirnezami, S. Saeidnia, Y. Ajani, "Pharmacognostical Evaluation, Phytochemical Analysis and Antioxidant Activity of the Roots of Achillea tenuifolia LAM", Pharmacogn J, 4 (30), 14-19 (2012).

49. S. Habibatni, A. Zohra, H. Khalida, S. Anwar, I. mansi and N. Awadh, "In-vitro antioxidant, Xanthine oxidase-inhibitory and in-vivo Anti- inflammatory, analgesic, antipyretic activity of Onopordum acanthium", Int J Phytomedicine, 9 (1), 92 100 (2017).

50. G. Escher, j. Santos, N. Rosso, M. Marques, L. Azevedo, M. Carmo, et la., "Chemical study, antioxidant, anti-hypertensive, and cytotoxic/cytoprotective activities of Centaurea cyanus $L$, petals aqueous extract", Food Chem Toxicol, 118, 439-453 (2018).

51. Y. Haliloglu, T. Ozek, M. Tekin, F. Goger, K. Baser and G. Ozek, "Phytochemicals, antioxidant, and antityrosinase activities of Achillea sivasicaÇelik and Akpulat", Int J Food Prop, 20 (1), 693-706 (2017).

52. A. Ardestani and R. Yazdanparast, "Antioxidant and free radical scavenging potential of Achillea santolina extracts", Food Chemistry, 104 (2007), 21-29 (2006).

53. W. Alsheikh, G. Sabbagh and A. Kitaz, "Evaluation of Radical Scavenging Activity, Total Phenolics and Total Flavonoids Contents of Cistus Species in Syria", Int J Pharmacogn Phytochem Res, 8 (7): 10711077 (2016).

54. S. Kesarkar, A. Bhandage, S. Deshmukh, K. Shevkar and M. Abhyankar, "Flavonoids: An Overview", J Pharm Res, 2 (6), 11481154 (2009).
55. G. Zenging, M. Locatelli, S. Carradori, A. Mocan and A. Ktumsek, "Total Phenolics, Flavonoids, Condensed Tannins Content of Eight Centaurea Species and Their Broad Inhibitory Activities against Cholinesterase, Tyrosinase, $\alpha$-Amylase and $\alpha$ Glucosidase", Not Bot Horti Agrobo, 44 (1), 195-200 (2016).

56. D. Benedec, B. Hanganu, I. Oniga, L. Filip, C. Bischin, R. Dumitrescu, et la., "molecules Achillea schurii Flowers, Chemical, Antioxidant, and Antimicrobial Investigations". Molecules, 21 (1050), 1-12 (2016).

57. B. Inalegwu and O. Sodipo, "Phytochemical screening and haemolytic activities of crude and purified saponins of aqueous and methanolic extracts of leaves of Tephrosiavogelii Hook. F", Asian J plant Sci Res, 3 (5), 7-11 (2013).

58. D. Joujeh, R. Lahdo and J. Ghrewati, "Evaluation of hemolytic and AntiHemolytic Activity of the Arial parts of Sonchus oleraceus Extracts", Int. J. Pharm. Sci. Nanotech., 10 (3), 3745-3751 (2017).

59. J. Ghrewati , R. Lahdo and D. Joujeh, "Hemolytic and Anti-Hemolytic activity of Methanolic and Aqueous Extracts of Matricaria chamomilla in-vitro", Journal of Aleppo University, 125, (2017).

60. J. Ghrewati , R. Lahdo and D. Joujeh, "Hemolytic and Anti-Hemolytic Activity of Methanolic and Aqueous Extracts of Silybum marianum In Vitro", Journal of Aleppo University, 123, (2017).

61. S. Konyalioglu, C, "The protective effects of Achillea $L$. species native in Turkey against $\mathrm{H}_{2} \mathrm{O}_{2}$-induced oxidative damage in human erythrocytes and leucocytes", $\boldsymbol{J}$ Ethnopharmacol, 102, 221-227, (2005).

62. B. Poljsak, J. Ionescu, "Pro-Oxidant vs. Antioxidant Effects of Vitamin C", Handbook of vitamin $C$ research, In: Daily requirements, dietary sources and adverse effects, H. Kucharski and J. Zajac (eds.), Nova Science Publishers, 2009, p. 153.

63. M. Levine, C. Rushad, B. D. Jae, S. Rumsey and Y. Wang, "Does vitamin $\mathrm{C}$ have a prooxidant effect?. Nature", Macmillan Publishers Ltd., 395 (6699), 231-231, (1998). 


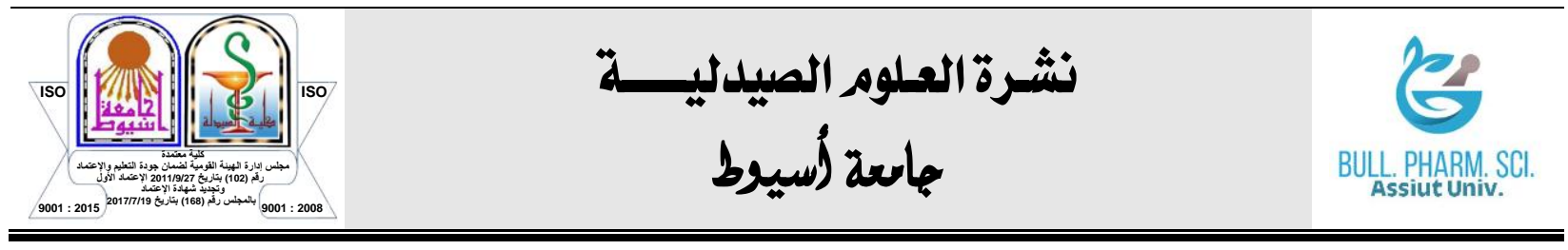

\title{
دراسة كيميائية نباتية واستقصاء التأثثر الواقي ضد الضرر التأكسدي لكريات الام

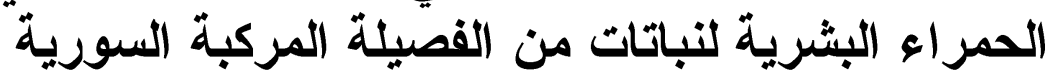

\author{
محمد كنان الجاجه' - رغداء لحدو' - عدوية قيطل ' \\ 'قسم العقاقير والنباتات الطبية ، كلية الصيدلة ، جامعة حلب ، سوريا \\ ' قسم الكيمياء الحيوية والأحياء الدقيقة ، كلية الصيدلة ، جامعة حلب ، سوريا
}

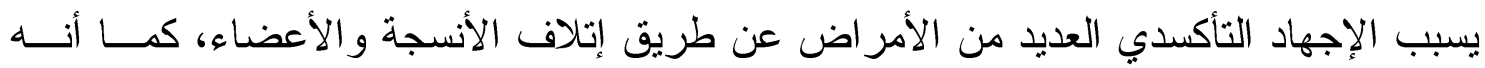
يسبب أكسدة الليبيدات وتحطيم الحمض النووي DNA. لذلك في وقتنا الحالي يهتم الباحثون في النباتات الطبية للاستفادة من مكو انتها المضادة للأكسدة.

تهدف الدراسة الحالية في التحري عن التأثير الانحلالي و الفعالية الواقية للانحلال و الكثف عن

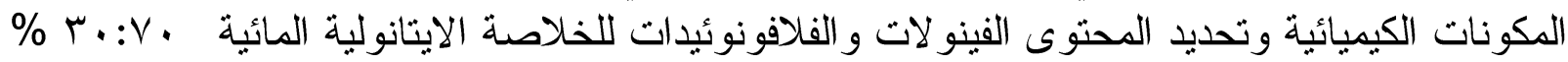

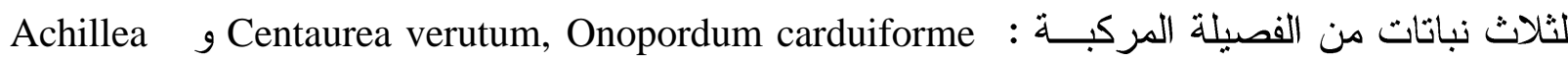
santolina

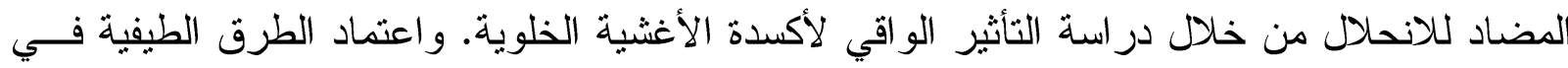

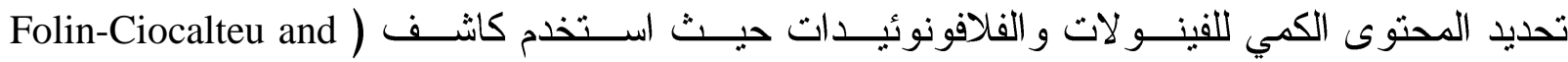
(aluminum chloride

بينت النتائج أن الخلاصة النباتية لها تأثير آحالا منخفضا عند التر اكيز (1-0 مجم/مل)، كمــا

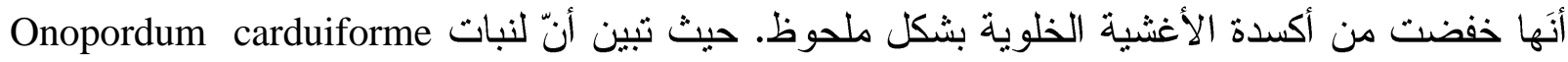

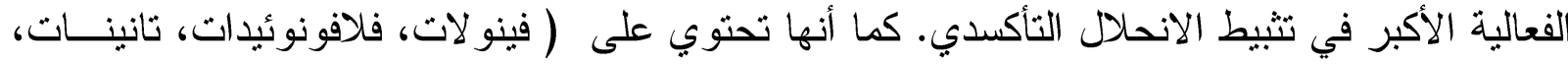

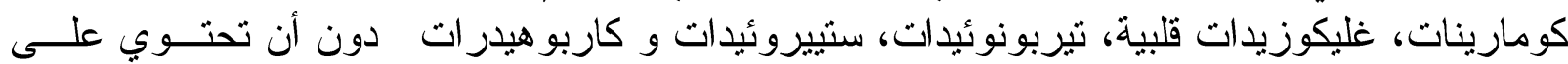

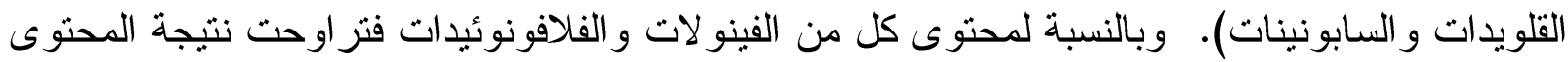

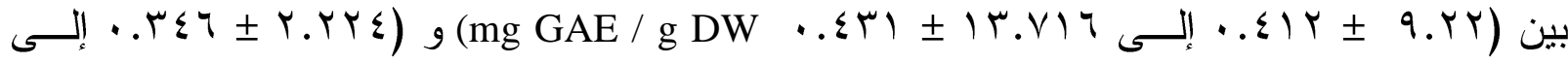

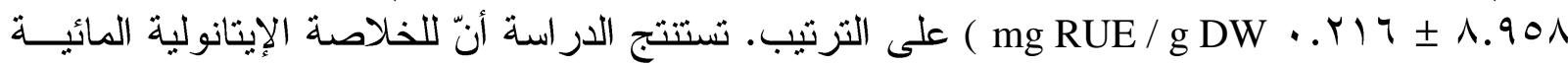

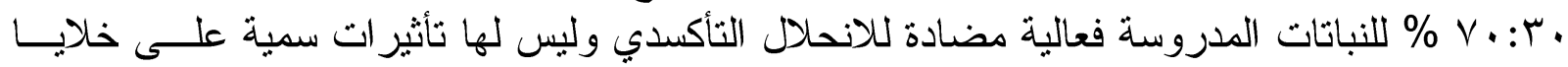

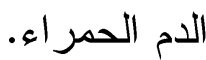

